\title{
Global aphasia in a case of bilateral frontal lobe infarcts involving both caudate nuclei
}

\author{
Davala Krishna Karthik, ${ }^{1}$ Vikram Khardenavis, ${ }^{2}$ Sharvari Kulkarni, ${ }^{3}$ \\ Anirudda Deshpande ${ }^{4}$
}

'Department of Radiology, Surya Diagnostics, Warangal, Telangana, India

${ }^{2}$ Department of Medicine, Miraj Medical College, Miraj, Maharashtra, India ${ }^{3}$ Department of Medicine, Maharashtra Institute of Medical Education and Research, Pune, Maharashtra, India

${ }^{4}$ Department of Neurology, Vinayaka Neuro Multispecialty Clinic, Warangal, Telangana, India

\section{Correspondence to} Anirudda Deshpande, dr.anirudda.deshpande@gmail. com

Accepted 17 October 2017

\section{DESCRIPTION}

We report a 50-year-old man with history of systemic hypertension, nicotine addiction and a folk singer by profession was brought to the hospital with history of abrupt onset of speech arrest at the peak of a high note during his stage performance. His co-performer friend noticed that he was unable to restart his song performance despite back stage prompting. He appeared clueless and unresponsive with expressionless face all of a sudden. His

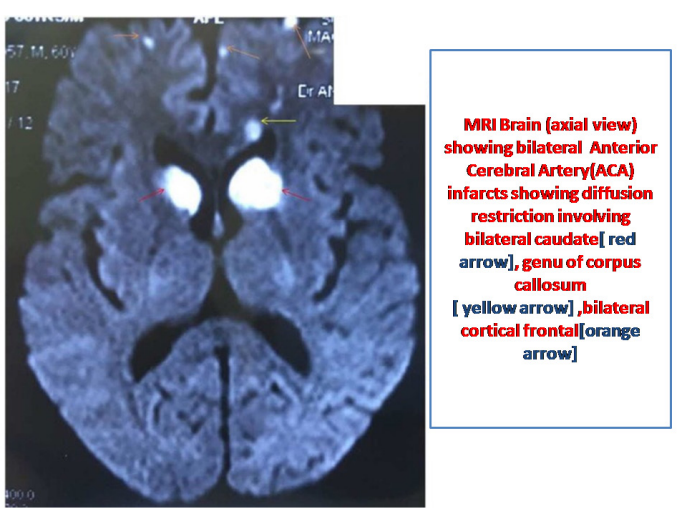

Figure 1 The diffusion-weighted imaging and apparent diffusion coefficient sequences of MRI brain axial view shows bilateral caudate, bihemispherical (left?right) cortical frontal, genu of corpus callosum diffusion restriction. MRI, magnetic resonance imaging.

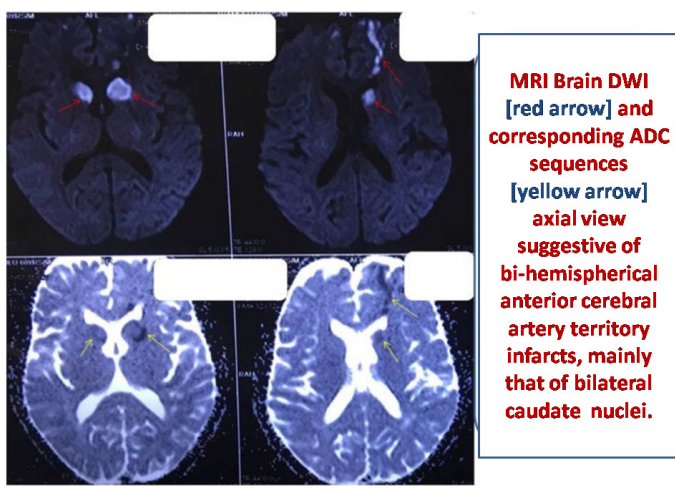

Figure 2 The diffusion-weighted imaging (DWI) and apparent diffusion coefficient (ADC) sequences of MRI brain axial view shows bilateral caudate, bihemispherical (left?right) cortical frontal, genu of corpus callosum diffusion restriction. ADC, apparent diffusion coefficient; DWI, diffusion weighted imaging; MRI, magnetic resonance imaging.

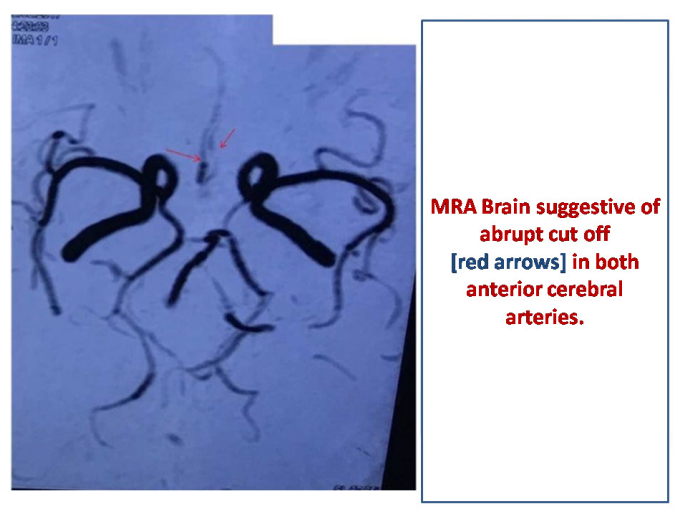

Figure 3 Magnetic resonance angiography (MRA) shows bilateral anterior cerebral arteries (A1) thrombosis.

relatives were certain that there was a dramatic change in patient's personality (from an extrovert to an introvert). The patient seemed disinterested in his surroundings. He seemed to have a 'vacant stare'. On examination, his blood pressure was $170 / 100 \mathrm{~mm} \mathrm{Hg}$. He was conscious, alert, but unresponsive to simple verbal commands. There was no speech output. Fundus examination showed grade 1 hypertensive retinopathy, no papilloedema. Motor functions were preserved. MRI of brain with magnetic resonance angiography (MRA) was done in view of strong possibility of cerebrovascular accident. The diffusion-weighted imaging and apparent diffusion coefficient sequences of MRI brain showed bilateral caudate, bihemispherical (left $\rightarrow$ right) cortical frontal, genu of corpus callosum diffusion restriction (figures 1 and 2). The MRA showed bilateral anterior cerebral arteries (ACA) thrombosis (figure 3). MRA indicates bilateral A1 occlusion, and infarction areas are corresponding to the territory of A1 perforating arteries. Other ACA territories are spared possibly because of collateral blood supply.

At 6-month follow-up, the patient seemed to have had very minimal improvement in his cognitive

\section{Learning points}

- Affection of bilateral caudate nuclei can manifest in different ways involving multiple cognitive domains.

- Global aphasia is a rare manifestation of bilateral caudate infarcts. 
symptoms despite good compliance to antiplatelet and antihypertensive medications.

Global aphasia is a non-fluent aphasia, which impairs both expressive and receptive language skills. It leads to severe impairment of production, comprehension and repetition of language. ${ }^{1}$

Caudate lesions (unilateral or bilateral) can rarely manifest as global aphasia. ${ }^{23}$

Contributors DKK and VK made substantial contributions to the conception and design of the work, acquisition, analysis and interpretation of the data. SK and AD were involved in drafting the work and revising it critically for important intellectual content. $A D$ approved the final version to be published.

Competing interests None declared.
Patient consent Obtained.

Provenance and peer review Not commissioned; externally peer reviewed.

(C) BMJ Publishing Group Ltd (unless otherwise stated in the text of the article) 2017. All rights reserved. No commercial use is permitted unless otherwise expressly granted.

\section{REFERENCES}

1 Kemmerer D. Cognitive neuroscience of language. New York: Psychology Press, 2015:86

2 Kumral E, Evyapan D, Balkir K. Acute caudate vascular lesions. Stroke 1999:30:100-8.

3 Paciaroni M, Agnelli G, Caso V, et al. Manifestations of stroke. Frontiers Neurology Neuroscience. Basel: Karger, 2012;vol 30:137-40.

Copyright 2017 BMJ Publishing Group. All rights reserved. For permission to reuse any of this content visit

http://group.bmj.com/group/rights-licensing/permissions.

BMJ Case Report Fellows may re-use this article for personal use and teaching without any further permission.

Become a Fellow of BMJ Case Reports today and you can:

- Submit as many cases as you like

Enjoy fast sympathetic peer review and rapid publication of accepted articles

- Access all the published articles

Re-use any of the published material for personal use and teaching without further permission

For information on Institutional Fellowships contact consortiasales@bmjgroup.com

Visit casereports.bmj.com for more articles like this and to become a Fellow 